\title{
Review
}

\section{Rationalism, pluralism, and freedom}

\author{
Jacob T. Levy \\ Oxford University Press, New York, 2014, xiii+336pp., ISBN: 978-0198717140
}

Contemporary Political Theory (2016) 15, e18-e21. doi:10.1057/cpt.2015.41;

published online 7 July 2015

For Jacob Levy, Cinderella is a 'rationalist' tale. Cinderella's stepmother oppresses her; the handsome prince (who must represent the state) saves her. These aspects, fairy godmothers and pumpkin coaches notwithstanding, reveal the true meaning of the fairytale. Cinderella symbolizes the ways families, religions, and small-minded local governments constrain and abuse individuals, preventing them from transcending their lot in life. Such a view of the relationship between the individual and the state is typical, Levy would claim, of 'rationalist' approaches to liberalism.

Levy does not actually discuss Cinderella in Rationalism, Pluralism, and Freedom, but the story illustrates one horn of the insoluble but productive dilemma Levy thinks characterizes liberal political theory. For Levy, the liberal tradition (and its historical predecessors) can be divided into opposing camps: pluralism and rationalism. 'Pluralists' focus on the gains for freedom that come from citizens' connections to and embeddedness within cultural, religious and voluntary associations. As a consequence, pluralists respect the different and sometimes illiberal norms and decision-making procedures of 'intermediate' or 'purposive' groups, as Levy calls them: universities, churches, fraternal orders, ethnic and linguistic organizations, and the like. This is the alternative to the other liberal perspective my tongue-in-cheek reading of Cinderella provides. Cinderella-type liberals are 'rationalists'. They focus on the way in which universal egalitarian norms and centralized states enable human freedom and often serve to liberate citizens from oppression at the hands of tradition-bound (or sometimes merely despotic) local power (pp. 1-41).

Levy's book is both analytically and historically ambitious. Historically, Levy argues that the distinction between rationalism and pluralism stretches back to the high middle ages, a time of associational richness when Europeans founded the first guilds, monastic orders and universities, and consolidated and centralized the Catholic Church. All these groups were separate from their 'states' and governed themselves according to their own law-like norms. This led a to a 'lumpy' political landscape in which legal norms varied not only territorially but also depending on a person's status and the groups to which they belonged (pp. 87-105). Later, to resist 
early-modern absolutism, several thinkers re-conceptualized this lumpy, pluralistic political variety as Europe's 'ancient constitution'. Ancient constitutionalism, Levy argues, is an alternative tradition of political thought that is contemporaneous with but distinct from classical republicanism and the social contract tradition (pp. 106-140). Montesquieu is the earliest canonical pluralist/ancient constitutionalist, and his work is the linchpin of Levy's later historical analysis. In contrast to Voltaire, who emphasized the enlightening possibilities of the absolutist state (particularly its ability to resist the Church), Montesquieu showed how local political organizations (particularly the parlements), each with different privileges and legal traditions, served to create a moderate and free political environment in France before absolutism (pp. 141-170).

Levy traces the development of rationalist and pluralist liberalisms through responses to Montesquieu's work, from the revolutionary era through the nineteenth century, and the British pluralists (pp. 171-252). Levy demonstrates how disagreements about local power and variety separate Paine from Madison and Mill from Tocqueville. He shows that the British pluralists deserve to be categorized firmly within the liberal tradition: their interest in intermediate political groups stems from engagement with Lord Acton as much as German political thought, and Acton's similar views stem from his reverence for Montesquieu.

Levy's purpose is not only historical; he also shows how thinkers' rationalism or pluralism impacts their judgment. Infamously, Lord Acton was so enamored of local autonomy that he claimed the US Confederacy was the brightest hope for freedom in the modern world. Such mistakes are a theme of Levy's survey: Voltaire was similarly unwilling to see how his hatred of the Catholic Church led him to embrace an absolutism that could be just as oppressive, and J.S. Mill could not see the dangers to freedom centralized, paternalistic imperialism inevitably posed. Levy wants to show how and why 'Tocqueville was right about associations but wrong about the family, that Mill was right about the family but wrong about imperialism, that Acton was right about nationalism and wrong about the American Civil War' (p. 3). For Levy, Tocqueville's and Acton's pluralism blinded them to intermediate groups' oppressive tendencies while Mill's rationalism, in turn, prevented him from seeing the similarly oppressive tendencies of a centralized and 'civilizing' empire.

As Levy's historical survey implies, he does not believe there is any possible reconciliation between the rationalistic and pluralistic tendencies in liberalism. Rather, he argues that the tension is necessary to any theory of freedom. Analytically, Levy shows that any liberationist project is potentially oppressive: freeing people from dogmatic religions or oppressive families requires an institution more powerful than such intermediate groups (the state). The power the state uses to liberate can also and is often used to oppress. This is particularly likely when states mistake free expressions of identity as evidence of oppression. So, as Levy notes, for many in Quebec a Muslim girl's decision to wear a headscarf is evidence of her oppression at the hands of a patriarchal religious group, but the crucifixes prominently hung in 
provincial offices and courthouses are 'mere' expressions of tradition (pp. 260-261). The difficulty is that empowering local groups - the pluralist solution - also does not eliminate oppression. Groups powerful enough to resist states are also powerful enough to oppress their members. Indeed, conflict between groups and the state creates vicious circles in which mutual suspicion generates surplus oppression: the state, convinced that a group is oppressing its members, clamps down hard on it; the group, in order to maintain its traditions, throws up higher barriers to entry, marshals its troops, imposes stricter standards of practice or belief and refuses to compromise with the outside world. Levy's analysis suggests that pluralistic competition among groups and with the state is likely to lead to just such an outcome - and that otherwise more open-minded group members may choose dogmatic group leaders precisely because they believe such dogmatism is necessary for their group's flourishing in the face of state or majority suspicion (pp. 56-86). Potential for oppression is endemic to any liberation attempt, whether rationalist or pluralist in nature; Levy deftly alerts his readers to this sobering reality.

Because Levy's analytic thesis is so sobering, Rationalism, Pluralism, and Freedom is somewhat dissatisfying. Levy does not offer much advice about what to do to balance the freedoms of groups and individuals. Of course, Levy cannot consistently hold that there is one philosophical principle (let alone one or a set of plausible policy solutions) that can solve all such conflicts. But he could bring his well-developed analysis of the dueling possibilities of state and group oppression to bear on more contemporary political problems. Near the conclusion, Levy offers an illuminating, pluralist analysis of academic freedom. Understanding academic freedom requires recognizing that universities are not states, they are intermediate groups organized for the sake of academic inquiry. Academic freedom is a norm designed to assist universities in that pursuit. So it may be permissible for some universities to adopt 'all comers' rules in regulating their student clubs in order to enhance critical exchange among students who disagree, even though such rules would be extreme infractions of freedoms of association were a state to impose them. Similarly, universities need not provide forums for just anyone to speak (they should not be subject to the same rigorous free speech protections that apply to the US Government), but they must ensure that whatever invitations they make further the university's purpose. Levy might have forestalled some of the dissatisfying sobriety of his conclusions had he provided more illuminating analysis of this sort - work the book sets him up to do well.

Finally, there is a perplexing omission in Levy's analysis. Levy adopts the term 'rationalism' from Hayek's pejorative use of it - though Levy uses it differently (p. ix). Indeed, Levy may be more distant from Hayek than he admits: For Hayek, rationalism is a term of opprobrium he used to condemn any attempt to influence market allocations outside of the price system. But Montesquieu, Levy's hero, was so enamored of local variation that he opposed the French government's attempt to impose a single system of measurement on the entire state (p. 188). Levy's pluralists 
also favor local variation in law. Both kinds of variation create significant barriers to trade and impede the development and spread of markets. So, for Levy, are market libertarians (that is, Hayek) rationalists? Does the same rationalist-pluralist tension Levy observes in politics apply to the economy? Levy does not address these questions, though they hang over his analysis and are relevant to many live political questions.

Rationalism, Pluralism, and Freedom's sobering thesis and avoidance of economic issues does not ultimately distract from Levy's considerable achievement. Levy has rehabilitated a neglected tradition in liberal political thought, demonstrated its salience for politics today and shown the defensibility of some of its key theoretical claims. And he is admirably honest, advocating an eyes-wide-open view of states, intermediate groups, and their interactions, for political good or ill. Most importantly of all, Levy's book is generative: its sensitive discussion of theoretical issues both historical and contemporary will inspire much further discussion, inquiry and scholarship.

Benjamin Hertzberg
Brigham Young University, Provo, UT 84602, USA 